\title{
Leadership, Knowledge Management, and Human Capital Development
}

\author{
Sakher Alnajdawi, Rami Hanandeh, Belal Yousef Barhem, Alhareth Mohammed \\ Department of Management, Business Management and Human Resource Management, Faculty of Business, \\ Amman Arab University, Amman, Jordan
}

\begin{abstract}
This research highlights the need to develop a framework for leadership, human capital development, and knowledge management by reviewing existing literature in the field of research. The main aim of this research is to propose a model which supports the relationship between leadership (servant leadership, transformational leadership) and human capital development. The study also proposes that knowledge management (knowledge sharing, knowledge acquisition) will moderate the relationship between leadership (servant leadership, transformational leadership) and human capital development. A set of propositions that represent an empirically-driven research agenda, and also describe the relationships between the focal variables are presented to enhance audience's understanding within a business context.
\end{abstract}

Keywords: leadership, human capital, knowledge management, transformational leadership, servant leadership, knowledge sharing, knowledge acquisition

\section{Introduction}

Leadership has been one of the core management functions. It has gained attention in almost all sorts of organizations ranging from business and education to social organizations. Although administrative leadership has long been a subject of interest, the scientific research on leadership began in the early 19th century. Researchers have found leadership behaviors to be important determinants of organizational success (Bass, 1990).

Human Capital theory as mentioned by Lepak and Snell (1999) emphasizes the labor cost to retain on investment, developing employee knowledge and skills. According to Lonska and Mietule (2015), human capital is a set of person's abilities and skills, having direct impact on one's economic and social activity potential. The concept of human capital is primarily related to the economic behavior of individuals, especially in the way in which their accumulated knowledge and skills boost their productivity and income, thereby

SakherAlnajdawi, PhD, Assistant Professor, Department of Management, Business Management and Human Resource Management, Faculty of Business, Amman Arab University, Amman, Jordan.

Rami Hanandeh, PhD, Assistant Professor, Department of Management, Business Management and Human Resource Management, Faculty of Business, Amman Arab University, Amman, Jordan.

Belal Yousef Barhem, PhD, professor, Department of Management, Business Management and Human Resource Management, Faculty of Business, Amman Arab University, Amman, Jordan.

Alhareth Mohammed, PhD, Associate Professor, Department of Management, Business Management and Human Resource Management, Faculty of Business, Amman Arab University, Amman, Jordan.

Correspondence concerning this article should be addressed to Sakher Alnajdawi, Jordan Street-Mubis, Tel. +962 64791400 , Fax. +962 6 4791414P.O. Box 2234 - Amman 11953 - Jordan -Email: aau@aau.edu.jo. 
increasing the productivity and income of the society on the whole. Human capital plays a vital role in creating a competitive advantage by fostering innovative trends for the organization (Alnajdawi, Emeagwali, \& Elrehail, 2017).

Knowledge Management is defined as "the systematic process of discovering, selecting, organizing, distilling, and presenting information in a way that develop an employee's comprehension in specific area of interest" (Mertins, Heisig, \& Vorbeck, 2003). According to Elrehail, Alzghoul, Saydam, Alnajdawi, and Al-Ararh (2016) knowledge management plays a leading role in the development cycle giving organization a competitive advantage over their competitors. Knowledge sharing is a process that enables employees to share knowledge with each other, leading to developing knowledge, skills, and ability among employees.

On other hand, knowledge acquisition is a process to ensure that the knowledge is readily available in the times when organization needs it. Elrehail, Trad, and Algraibeh (2013) mentioned that knowledge acquisition is "the way that you can extract information, make it usable and listed in sufficient way to retrieved in the time we need" (p.316-322). Both of these knowledge management processes are important for the successes of any organization. By adding leadership and knowledge management process together they will enhance the development of human capital which is one of the inimitable assets of any organization.

In the current study a model is proposed which incorporates the impact of leadership style on human capital development using knowledge management practices. It will argue that leadership plays a significant role in the human capital development, to moderate the role of knowledge management practices and their impacts on human capital development.

\section{Contribution of the Study}

The role of leadership in developing effective human capital is already established. Knowledge sharing and acquisition are both factors affecting the human capital development. While knowledge sharing affects at the individual level, knowledge acquisition operates at the organizational levels. Therefore, this study tries to outline and test the impact of two leadership styles (i.e. transformational \& servant) which will be the first contribution of this research. Secondly the study will look into the moderation effect of knowledge management processes (i.e. knowledge sharing \& acquisition), and how they will strengthen the relationship between leadership and human capital development. Throughout, the study takes into consideration, the practical implications for the practitioners in the human resource management.

\section{An Overview of Prior Studies}

\section{Leadership}

Riaz and Haider (2010) noted that effective leaders have the ability to lead organizations to success by taking into account the changes in the world which require an effective leadership to face these problems and changes. Leadership consists of directing and coordinating the work of group members (Fiedler, 1967). Leadership is exercised when a group of individuals mobilize political and other resources to arouse, engage, and satisfy the motives of followers (Burns, 1978). Moreover, Daft (1999) has added another element to the idea of leadership describing it as an influence that occurs between leaders and their followers. The influence produces the outcomes the leader wants so that both leader and followers are actively involved in the pursuit of a change aimed at reaching the required goals. 


\section{Human Capital}

Human capital is referred to as the "degree of competence and capabilities possessed by employees" (Wiig, 1997, p. 399-405). Wiig's human capital theory recommends comparing the degree of investment on skills and knowledge development with future benefits such as salary progression or authority and status (Becker, 1975).

As mentioned in the World Economic Forum, growth in educational systems in many countries could respond to the market demand and fill the gap of skilled and trained employees to support business activity. Becker (1993) mentioned that human capital is a store of experience, skills, and motivation. Capital investment areas include: education, experiences, health care, internal migration, and data. Most developing countries face many problems in their education system, so they should develop a leadership perspective that can enhance the education system. Since the most important aspect of this problem is human capital, leaders of the higher education sector should take into consideration to start development programs that enhance their staff. Human capital is one of the organization sources that give the firm a competitive advantage that can't be subsisted by another (Zubaidi, , Sadalia, \& Absah, 2018).

\section{Knowledge Management}

According to Fernandez and Sabherwal (2010) the term knowledge is concerning to justifying the true belief and now a day's organizations are giving the attention to this concept because of his ability to have effect on the organization quality, productivity, and performance capacity. Knowledge management is concept that's concerning of the organizations that's doing what is needed to get the most out of knowledge resources. Based on Alrubaiee, Alzubi, Hanandeh, and Ali (2015), knowledge management is a combination of ideas, concepts, and actions taken by the organization to acquire, store, transfer, and share knowledge to meet their cognitive needs. The study also considered knowledge to be the most important intangible asset.

\section{Development of Propositions}

The challenge in managing changing economic markets and the environment is how to adopt a leadership management with effective practices to deal with the environment dynamics. Transformational leadership represents the ability of a leader to affect and change not only the firm's culture but also its profitability (Koednok, 2013). Transformational leadership has been defined as a set of ethical and professional behaviors by leaders to motivate their subordinates to accomplish high-value works that they were not expected to accomplish by raising challenges for them and to convince them of the importance and value of their work and to encourage these subordinates to employ their energies in the interest of the community (Al-Kharabsheh \& Al-Maani, 2016). Their study justified the importance of adopting transformational leadership processes and their positive impact on administrative creativity. The study also recommended the need to increase the degree of delegation and urge employees to take responsibility. McCracken, McIvor, Treacy, and Wall (2017) argue that corporate leadership is considered as a key role in human capital as it facilitates the innovative and transformational climate, transformational leadership related to innovative skills abilities and it is considered as a leadership style that transforms and converts followers to increase their self-interest and to justify their beliefs. Subsequently, it is considered as the leader's ability to motivate the employees to accomplish what the managers planned in the strategic planning to reduce the gap between what the followers have done and what the organization was planning and expected to be done. The results showed that the organizational environment and strategic management are playing a role in developing both human and social capital. 


\section{Proposition 1: Transformational Leadership Will Positively Impact the Human Capital Development}

Servant Leadership, appears by a leader following the mental values to serve other employees or people, whether in their own organization or in society, so server leadership is simply helping others to find and discover their mental in order to promote predilection and trust in others and respect for their dignity (Ayranci \& Semercioz, 2011). The importance of serving leadership stems from being the only type of leadership capable of balancing morality, accomplishing tasks, enhancing interests, and increasing the well-being of the owners of origin. And to promote success, increase healing and equality, an environment is created that combines the interests of the organization with its main stakeholders and its employees who are developing and they are able to search, find themselves, and develop with the organization, the spirit of leadership is created (Roberts. 2014). The new idea in the concept of Servant Leadership is a model that is clearly based the service of others by the leader and one of the conditions of moral leadership and not the service in the functional sense, but in the spirit of service manifested in every behavior beginning with the self-family and group to the smallest and largest organizations (Aziz Abdullah \& Mohammed, 2018). According to Barbuto and Gottfredson (2016) servant leadership, namely: Altruistic Calling, Emotional Healing, Wisdom, Persuasive Mapping, Organizational Stewardship, the researcher considered that the recent developments have affected the selection of companies for their labor force in two ways, in the first place it is a challenge to attract skilled employees, while on the other hand considered it an opportunity to train and develop employees.

\section{Proposition 2: Servant Leadership Will Positively Impact the Human Capital Development}

As Bass and Riggio (2006) stated, leadership us considered key role that plays a critical part in developing the organizational performance and its transformational leadership can be defined as a style of leadership that aims to realize the goals of an organization by creating employees awareness, and the concept of transformational leadership has attracted the attention of many researchers because of its impact on human capital and firms' overall performance. According to Jelenic (2011) study knowledge management plays an important role in reducing production and productivity vulnerability and increasing control over resource waste reduction. Knowledge management can also be considered an important factor in developing employee performance and creating an effective environment. The main objective of knowledge management is to create an enabling environment for individuals to communicate and exchange knowledge more efficiently. Therefore the study finds that, knowledge management plays an important role in influencing and facilitating the impact of transformational leadership on human capital as a strategy through which the skills, capability, commitment, loyalty, and knowledge will be transferred from departments to employees and to employees during work.

Based on Gelard, Boroumand, and Mohammadi's (2014) research, knowledge management acts a vital role in reducing production and productivity vulnerability and increasing control over resource waste reduction. Knowledge management can also be considered an important factor in developing employee performance and creating an effective environment. The main objective of knowledge management is to create an enabling environment for individuals to communicate and exchange knowledge equations more efficiently. Transformational leadership has been found to validate employee commitment and thus influence human capital by increasing the sensitivity of the leader toward each worker thereby increasing organizational commitment by engaging staff in goal setting, operations, visibility, and expression of the importance of workers in the organization, and the development of workers. To accomplish all of the above, it is necessary to use knowledge sharing to facilitate the transmission of namely, information, skills, or expertise (Ayranci, 2017). 


\section{Proposition 3: Knowledge Sharing Will Moderate the Relationship Between Transformational Leadership and Human Capital Development}

Knowledge sharing is the intellectual human capital which consists of what people learned from sharing the knowledge between employees during the education and practical life's and they referred the fact that in these competitive and rapidly changing environments, companies have created pressures and opportunities. Companies have realized that their strength lies in transforming resources into cognitive capabilities. The study emphasizes the ability of wise leaders helped by knowledge sharing in influencing organizations' creativity in positive way (A. Hanandeh, R. Hanandeh, \& R. Hanandeh, 2015). The strength of knowledge lies in the generosity, it gives employees power to increase creativity and synergy between employees and organizations, which further meets the organizations' ambition to increase competitive and creative environments that affect their product and services privately and performance in general (Hanandeh, Del-Vecchio, \& Passiante, 2017). Servant leadership is the leadership that promotes the development of the skills of subordinates and the translation of workers' ethics into cooperation between workers to promote the spirit of knowledge sharing and it may cause lower hidden knowledge by focusing on independence, efficiency, and relationship (Braam, 2017).

\section{Proposition 4: Knowledge Sharing Will Moderate the Relationship Between Servant Leadership and Human Capital Development}

Many studies have indicated the importance of the relationship between knowledge management and transformational leadership. For example, Rahmatipour and Alipour (2015) found that there is relationship between knowledge acquisition and transformational leadership style among managers of hospital libraries in Tehran. This result was supported from Petrash (1996) who stated that knowledge management is acquiring appropriate knowledge for appropriate people in appropriate time in order to decide exactly. Politis (2002) also in his study showed some dimensions of the transformational leadership effects on acquisition of knowledge in organization. Birasnav et al. (2013) studied the impact of transformational leadership and knowledge management process on product and process innovation. They indicated the relationship between implementation of knowledge management process activities such as acquisition, transfer, and application of knowledge will be positively related to transformational leadership in order to improve product and process innovation. According to Chen and Huang, (2009), achieving and sustaining competitive advantage mostly depends on to what extent organizations leverage and manage individual employee's knowledge. In this regards, firms establish knowledge management system in which organizational structure, technology, and culture support organizations to implement knowledge management process in the forms of acquisition, transfer, and application of knowledge. Acquiring knowledge from customers, suppliers, and external professional networks represents knowledge acquisition by any firms. Lyles and Salk (2007) argue that leaders having articulated goals identify useful external knowledge for their organizations and acquire knowledge to increase innovative performance. Transformational leaders also communicate the importance of the external knowledge to employees and improve employees' creativity through acquiring other firms. The study of Birasnav et al. (2013) also pointed out that transformational leaders have understood that traditional firms can be transformed into innovative firms only when human capital is created within the firms. For example, firm may empower employee to acquire new knowledge and develop human capital within firm by providing training to employees to improve their skills and Transforming employees' capabilities into organizational capabilities. In this regard, employees can gain new knowledge through socializing with leaders and other employees. Sarin and 
McDermott (2003) indicated that service firms mostly depend on the knowledge acquisition process to update new technologies and to add newness into their processes. The personal interactions between the mangers of different firms and their networking behaviors also support to acquire new knowledge. Bass and Riggio (2006) stated that transformational leaders highly concentrate on acquiring knowledge from external sources such as suppliers, customers, or research institutions. Many researchers provide support for the relationship between transformational leadership and knowledge acquiring, so visionary leaders or transformational leaders are constantly maintaining relationship with their suppliers and customer acquires knowledge to improve their employee's performance.

\section{Proposition 5: Knowledge Acquisition Will Moderate the Relationship Between Transformational Leadership and Human Capital Development}

Andre and Lantu (2015) stated that both leadership management and human capital management have similar goals to increase staff performance which ultimately will increase the performance of the company itself. The concept of leadership is how leaders communicate and help employees reach their goals. Human capital management is a system in which there are many measures and steps to improve staff performance. Based on the multiple case studies in Indonesia and the foreign state, the researcher identified the links between some of them and found that there is a relationship between human capital management and leadership. The combination of servant leadership and human capital management can create a strong relationship between staff and leaders within the company.

Deal, Altman, and Rogelberg (2010), Hight (2008), and Williams (2014) noted that organizations can improve their ability to attract and retain higher talent by strengthening and training their leaders to become servant leaders. They studied (Millennial) workforce and the need for leadership to develop human capital, and argued that there are qualified employees who are in the millennium looking for good results with servant leaders. Specifically, for many unique features of the millennium generation, they want repetitive and explicit performance feedback. They have worse health than previous generations; get a level of knowledge that comes out of high school less than previous generations; want to show their boss or manager as their friend; and they want their managers to be very supportive, beside them, and to have their best interests. Barbuto and Wheeler (2006) argue that leaders of wisdom possess a strong sense of awareness as well as the ability to apply knowledge gained through intermittent observation; service leaders who engage in knowledge are sensitive to the quality of knowledge they acquire and provide to their employees.

Laghmani et al. (2015) in their studies in higher education have pointed out that one of the important strategies in organizations is to produce value for clients and people who are considered as the most important resource for organizations, knowledge capital, and intangible assets. This includes the knowledge, skill, and attitude of the manufacturer and the capabilities, and competencies available in human resources known as human capital. In fact, organizations that have a systematic and strategic program in developing this type of asset can provide greater value to customers. One way to develop human resource capabilities and capabilities to produce value is efficiency-based education. The fact that great leaders are the great servants is the key to their majesty and magnitude. Dierendonck (2011) points out that servant leader has no problem in recognizing that they can benefit from the knowledge and experience of others.

Proposition 6: Knowledge Acquisition Will Moderate the Relationship Between Servant Leadership and Human Capital Development 


\section{Discussion and Future Research Direction}

This research paper reviews leadership, knowledge management, and Human Capital Development theories, together with extant literature and develops testable propositions. Horsman (2010) argues that servant leadership can solve many problems organizations face in the 21st century. Servant leadership serves employees by creating knowledge and skill in them, removing barriers and problems, encouraging creativity, innovation, and empowering employees.

First, many researchers argues that transformational leadership has an impact on the Human Capital development. According to McCracken et al. (2017) leadership is considered a key role in human capital as it facilitates the innovative and transformational climate, transformational leadership related to innovative skills abilities and it is considered as a leadership style that transforms and converts followers to increase their self-interest and to justify their belief. Accordingly, this allows the researchers to draw the conclusions that transformational leadership has a significant impact on the Human Capital development.

Second, from prior work the researchers proposed that servant leadership has an impact on the Human Capital Development. Barbuto and Gottfredson (2016) on their study argue that servant leadership affects work force in two ways, the first one is a challenge to attract skilled employees, while on the other hand it's considered as an opportunity to train and develop employees. This view allows the researchers to draw the conclusions that servant leadership has positive impact on the Human Capital Development.

Third, from the stream of research, the researchers proposed that knowledge sharing has moderate effect on the relationship between transformational leadership and human capital development. According to Ayranci (2017) and Gelard, Boroumand, and Mohammadi (2014), knowledge management can also be considered an important factor in developing employee performance and creating an effective environment, and it is necessary to use knowledge sharing to facilitate the transmission of namely, information, skills, or expertise in the light of transformational leadership. This view allows the researchers to draw the conclusions that knowledge sharing will moderate the relationship between transformational leadership and human capital development.

Fourth, the crucial point of KM is to make a balance between creation and application (Bi et al., 2017). Accordingly, the researchers proposed that knowledge sharing has moderate effect on the relationship between servant leadership and human capital development. Hanandeh et al. (2015) in their study argue that the ability of wise leaders helped knowledge sharing in influencing organizations' creativity in positive way. This view allows the researchers to draw the conclusions that knowledge sharing will moderate the relationship between servant leadership and human capital development.

Fifth, from a theoretical perspective, the positivist research stream has been most concerned with describing knowledge acquisition as moderate in the relationship between transformational leadership and human capital development. According to Lyles and Salk (2007), leaders having articulated goals identify useful external knowledge for their organizations and acquire knowledge to increase innovative performance. Birasnav et al. (2013) also pointed out that transformational leaders have understood that traditional firms can be transformed into innovative firms only when human capital is created within the firms. This view allows the researchers to draw the conclusions that knowledge acquisition will moderate the relationship between servant leadership and human capital development.

Sixth, the number of theoretical and empirical frameworks denotes that knowledge acquisition has a moderate effect on the relationship between servant leadership and human capital development. Laghmani et al. 
(2015), Dierendonck (2011), and Barbuto and Wheeler (2006) argue that leaders of wisdom possess a strong sense of awareness as well as the ability to apply knowledge acquisition through intermittent observation, leaders who engage in knowledge are sensitive to the quality of knowledge they acquire and provide it to their employees. This view allows the researchers to draw the conclusions that knowledge acquisition will moderate the relationship between servant leadership and human capital development.

Finally, the proposed research model (refer Figure 1) was built based on the reviewing of previous study to describe the impact relationship between leadership (servant leadership, transformational leadership) and human capital development, and clarifying of the moderating effect of knowledge management (knowledge sharing, knowledge acquisition) in the light of theoretical justification. Future research should also try to explore the following questions empirically:

1. What is the effect of Transformational Leadership on Human Capital Development?

2. What is the effect of Servant Leadership on Human Capital Development?

3. How do knowledge management practices moderate the relation between leadership style and Human Capital Development?

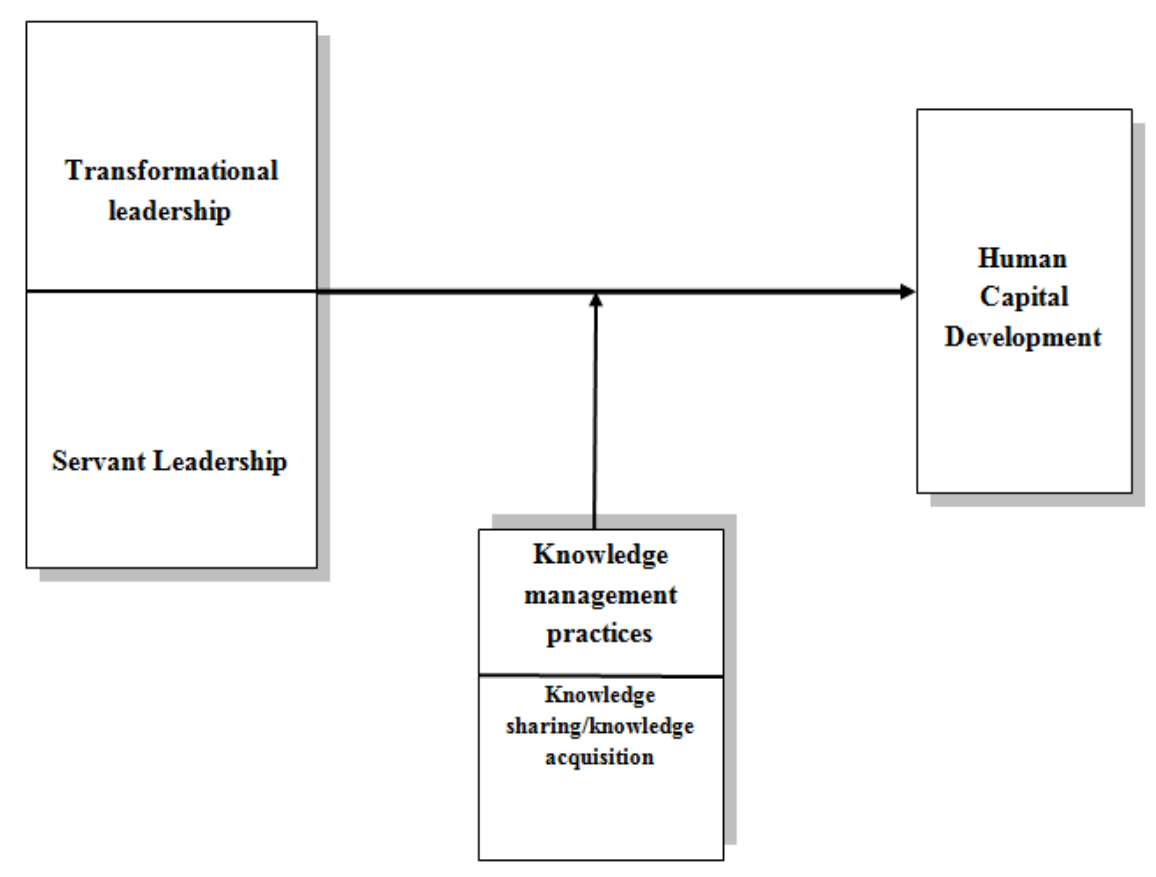

Figure 1. Proposed research model.

\section{References}

Allee, V. (1997). 12 principles of knowledge management. Training \& Development, 51(11), 71-74.

Alnajdawi, S., Emeagwali, O. L., \& Elrehail, H. (2017). The interplay among green human resource practices, organization citizenship behavior for environment and sustainable corporate performance: evidence from Jordan. Journal of Environmental Accounting and Management, 5(3), 171-184.

Alrubaiee, L., Alzubi, H. M., Hanandeh, R., \& Ali, R. A. (2015). Investigating the relationship between knowledge management processes and organizational performance the mediating effect of organizational innovation. International Review of Management and Business Research, 4(4), 989-1009.

Augusto Felício, J., Couto, E., \& Caiado, J. (2014). Human capital, social capital and organizational performance. Management Decision, 52(2), 350-364. 
Ayranci, E. (2017). Relationships between leadership perceptions and attitudes towards innovativeness: A research in a technopark in Istanbul. International Journal of Academic Research in Accounting, Finance and Management Sciences, 7(3), 171-181.

Ayranci, E., \& Semercioz, F. (2011). The relationship between spiritual leadership and issues of spirituality and religiosity: A study of top Turkish managers. International Journal of Business and Management, 6(4), 136.

Aziz, D. A., Abdullah, D. F., \& Mohammed, J. A. (2018). ممارسات القيادة الخادمة ودور ها في تعزيز الثقة التنظيمية. Journal of University of Human Development, 4(1), 13-31.

Bandura, A. (2008). Observational learning. In Donsbach, W. (Ed.), International encyclopedia of communication. Oxford: Blackwell, Vol. 7, pp. 3359-3361.

Barbuto Jr, J. E., \& Gottfredson, R. K. (2016). Human capital, the millennial's reign, and the need for servant leadership. Journal of Leadership Studies, 10(2), 59-63.

Bass, B. M., \& Riggio, R. E. (2006). Transformational leadership. Psychology Press.

Bass, B. M., \& Stogdill, R. M. (1990). Bass \& Stogdill's handbook of leadership: Theory, research, and managerial applications. New York: Simon and Schuster.

Becker, G. S. (1993). Nobel lecture: The economic way of looking at behavior. Journal of Political Economy, 101(3), 385-409.

Birasnav, M., \& Rangnekar, S. (2010). Knowledge management structure and human capital development in Indian manufacturing industries. Business Process Management Journal, 16(1), 57-75.

Birasnav, M., Rangnekar, S., \& Dalpati, A. (2011). Transformational leadership and human capital benefits: The role of knowledge management. Leadership \& Organization Development Journal, 32(2), 106-126.

Brislin, R. W. (1986). The wording and translation of research instruments.

Burns, J. M. (1978). Leadership. New York, NY: Harper \& Row.

Crawford, C. B. (2003). Exploring the relationship between knowledge management and transformational leadership. In ALE 2003 Conference, Anchorage, Alaska, USA, pp. 16-19.

Daft, R. L. (1999). Leadership: Theory and practice. Harcourt College Pub.

Elrehail, H. H., Trad, M. A., \& Algraibeh, K. M. (2013). Applying knowledge management oriented objectives into distance E-learning process and strategies. Management, 3(6), 316-322.

Elrehail, H., Alzghoul, A., Saydam, S., Alnajdawi, S., \& Al-Ararh, K. (2016). The role of knowledge sharing mechanism in the development of pricing strategy. International Journal of Online Marketing Research, 2(1), 53-61.

Fernandez, I. B., \& Sabherwal, R. (2010). Knowledge management systems and processes. ME Sharpe, Inc.

Fiedler, F. E., \& Chemers, M. M. (1967). A theory of leadership effectiveness.

Gelard, P., Boroumand, Z., \& Mohammadi, A. (2014). Relationship between transformational leadership and knowledge management. International Journal of Information Science and Management, 12(2), 67-82.

Greenleaf, R. K. (1977). Servant leadership: A journey into the nature of legitimate power and greatness. New York, NY: Paulist Press.

Gregory Stone, A., Russell, R. F., \& Patterson, K. (2004). Transformational versus servant leadership: A difference in leader focus. Leadership \& Organization Development Journal, 25(4), 349-361.

Gregory Stone, A., Russell, R. F., \& Patterson, K. (2004). Transformational versus servant leadership: A difference in leader focus. Leadership \& Organization Development Journal, 25(4), 349-361.

Gutierrez-Wirsching, S., Mayfield, J., Mayfield, M., \& Wang, W. (2015). Motivating language as a mediator between servant leadership and employee outcomes. Management Research Review, 38(12), 1234-1250.

Hair, J. F., Black, W. C., Babin, B. J., \& Anderson, R. E. (2010). Multivariate data analysis. 7th edition. Upper Saddle River, NJ: Prentice Hall.

Hanandeh, A., Hanandeh, R., \& Hanandeh, R. (2015). The usage of social media technology and customer relationship management in increasing innovation performance within the firm. American Academic \& Scholarly Research Journal, 7(7).

Hussain Haider, M., \& Riaz, A. (2010). Role of transformational and transactional leadership with job satisfaction and career satisfaction. Business and Economic Horizons, 1, 29-38.

Jelenic, D. (2011). The importance of knowledge management in Organizations-With emphasis on the balanced scorecard learning and growth Perspective. In Management, Knowledge and Learning, International Conference.

Lakshman, C. (2008). Knowledge leadership: Tools for top executives. New Delhi: Sage Response Books.

Lepak, D. P., \& Snell, S. A. (1999). The human resource architecture: Toward a theory of human capital allocation and development. Academy of Management Review, 24(1), 31-48. 
Liao, S. H., Wu, C. C., Hu, D. C., \& Tsuei, G. A. (2009). Knowledge acquisition, absorptive capacity, and innovation capability: an empirical study of Taiwan's knowledge-intensive industries. Technology, 11, 13.

Ling, Y. H., \& Jaw, B. S. (2011). Entrepreneurial leadership, human capital management, and global competitiveness: An empirical study of Taiwanese MNCs. Journal of Chinese Human Resources Management, 2(2), 117-135.

Lonska, J., \& Mietule, I. (2015). The impact of human capital development on the economic and social development of a country: empirical study. In Environment, Technology, Resources, Proceedings of the International Scientific and Practical Conference, Vol. 2, pp. 174-180.

McCracken, M., McIvor, R., Treacy, R., \& Wall, T. (2017). Human capital theory: Assessing the evidence for the value and importance of people to organisational success.

Mertins, K., Heisig, P., \& Vorbeck,, K., Heisig, P., \& Vorbeck, J. (2003). Knowledge management: concepts and best practices. Springer Science \& Business Media.

Roberts, G. E. (2014). Principles of servant leader human resource management (SLHRM). In Servant Leader Human Resource Management (pp. 1-38). New York: Palgrave Macmillan.

Schwab, K., \& Sala-i-Martin, X. (2013). World economic forum. In The Global Competitiveness Report 2013-2014, Geneva, Switzerland.

Spears, L. C. (1998), Insights on leadership: Service, stewardship, spirit, and servant-leadership. New York, NY: John Wiley \& Sons.

Walumbwa, F. O., Hartnell, C. A., \& Oke, A. (2010). Servant leadership, procedural justice climate, service climate, employee attitudes, and organizational citizenship behavior: A cross-level investigation. Journal of Applied Psychology, 95(3), 517.

Wiig, K. M. (1997). Integrating intellectual capital and knowledge management. Long range Planning, 30(3), 399-405.

Xiong, S., \& Deng, H. (2008). Critical success factors for effective knowledge sharing in Chinese joint ventures. In ACIS 2008 Proceedings, 95.

Zubaidi, A., Sadalia, I., \& Absah, Y. (2018). The factors affecting organizational citizenship behavior (OCB) of non-communicable diseases (NCD) officers in community health centers in Deli Serdang regency. Skyline Business Journal, 14(1), 12-32.

Jمournal of Education/Al MejlhAltrbwyh.30, 